УДК: 61-616+616.1

\title{
CARDIORENAL SYNDROME: THE REVIEW OF CURRENT UNDERSTANDING
}

\author{
OMUR ASLAM \\ United Kingdom, Royal Surrey County hospital
}

Summary.

Key words:

Introduction. The kidneys and heart rely on each other to function properly. For the kidneys to function, they require adequate blood flow, oxygen delivery and nutrients. If heart failure develops, cardiac output is reduced, which results in decreased renal blood flow, which can lead to reversible and sometimes irreversible kidney damage. For the heart to function, regulation of extracellular volume is required. If the extracellular volume is too low, the volume of blood is insufficient to maintain cardiac output, and if the extracellular volume is too large, fluid leaks out of the capillaries, resulting in edema.

Purpose. To study the relationship of the dynamic balance of the "kidney-heart" system in health and disease.

Material and methods. Review of modern and foreign literary sources; methods - description, analysis, abstracting.

Results and its discussion. 5 forms of cardiorenal syndrome, peculiarities of classification, pathogenesis, clinical manifestations, dynamics of imbalance in the "kidney-heart" system, issues of correction of these disorders are analyzed. They include the treatment of kidney diseases and cardiovascular pathology, prevention of the development of cardiovascular failure in accordance with modern recommendations; diet; quitting smoking, alcohol, nephrotoxic substances; control of body weight, blood pressure, glycemia; the use of angiotensin-converting enzyme inhibitors, angiotensin receptor antagonists or angiotensin receptor blockers, statins; decrease in intra-abdominal pressure and others.

Findings. Approaches to the prevention and treatment of cardiorenal syndrome in patients with kidney and heart damage are important. It is necessary to develop and introduce new approaches to nephroprotection in patients with cardiorenal syndrome, which is possible with the joint work of a multidisciplinary team.

kidneys, heart, cardio-renal syndrome.

Introduction. Cardiorenal Syndrome (CRS) involves a series of disorders involving heart and kidneys, in which acute or chronic dysfunction of one lead to acute or chronic dysfunction of an another resulting in reversible or irreversible damage..$^{[1]}$ An overview of working relationship between heart and kidneys involves heart pumping the blood containing oxygen and nutrients to perfuse organs and tissues including kidneys; while the kidneys regulate the extracellular volume, excrete metabolic waste products and allows the heart to function at maximum efficiency. Both organs rely on each other for their normal function. For kidney to function they require adequate blood flow and delivery of oxygen and nutrients. If heart failure develops, cardiac output is decreased leading to reduced renal blood flow which can lead to reversible and sometimes irreversible kidney damage, For heart to function it requires regulation of extracellular volume, if extracellular volume is too low there is an inadequate blood volume to support cardiac output and if extracellular volume is too high the fluid leaks out of capillaries resulting in edema. ${ }^{[2]}$

\section{Classification}

Acute Dialysis Quality group proposed a classification of CRS at a consensus conference in 2008. ${ }^{[9]}$

- Type 1: Acute CRS - Acute heart failure resulting in acute kidney injury (AKI). Example include Acute coronary syndrome leading to acute heart failure which leads to AKI.

- Type 2: Chronic CRS - Chronic heart failure leading to chronic kidney disease. Example include Chronic heart failure. 
- Type 3: Acute renocardiac syndrome - AKI leading to acute heart failure. Example include heart failure due to volume overload, metabolic disorders in uraemia and inflammatory surge.

- Type 4: Chronic renocardiac syndrome Chronic kidney disease (CKD) leads to chronic heart failure. Example include left ventricular hypertrophy and heart failure from CKD associated cardiomyopathy.

- Type 5: secondary CRS - Heart and kidney failure due to systemic process. Example include amyloidosis, sepsis and cirrhosis. . $^{[3,4,5]}$

Type 1 CRS occurs more commonly with more than one million patients in US are admitted to hospital every year with acute heart failure or acutely decompensated chronic heart failure (25\%). ${ }^{7} 9$ 10] Acute heart failure can be divided into four subtypes which included predominant right ventricular failure, cardiogenic shock, acutely decompensated chronic heart failure and hypertensive pulmonary edema with preserved left ventricular systolic function. ${ }^{\left[{ }^{[8]}\right.}$ Acute kidney injury appears more severe in patients with impaired left ventricular ejection fraction as compared with preserved left ventricular function in acute heart failure. ${ }^{[6]}$

In presence of acute decompensated heart failure in type $1 \mathrm{CRS}$, hemodynamic mechanisms play a crucial role. Reduction in efficient circulation fluid volume and increase in central venous pressure represents the main hemodynamic changes. Kidney and heart parameters can come back to normal if hemodynamic are restored. ${ }^{[11}{ }^{12]}$ Decrease in renal blood flow related to systemic nervous system and renin angiotensin-aldosterone system (RAAS) activation leads to decreased effective glomerular perfusion pressure, decreased renal blood flow and afferent vasoconstriction. Increased pulmonary, systemic congestion and central venous pressure leads to increased interstitial pressure with tubular collapse and progression to declining GFR. $\left.{ }^{[13} 1415\right]$

Non hemodynamic mechanisms include RAAS and sympathetic nervous system activation, abnormal proportions of nitric oxide and reactive oxygen species production and chronic inflammation. Abnormal regulation of inflammatory pathways activation and monocyte apoptosis is commonly seen in

Type 1: Acute CRS

Pathophysiology

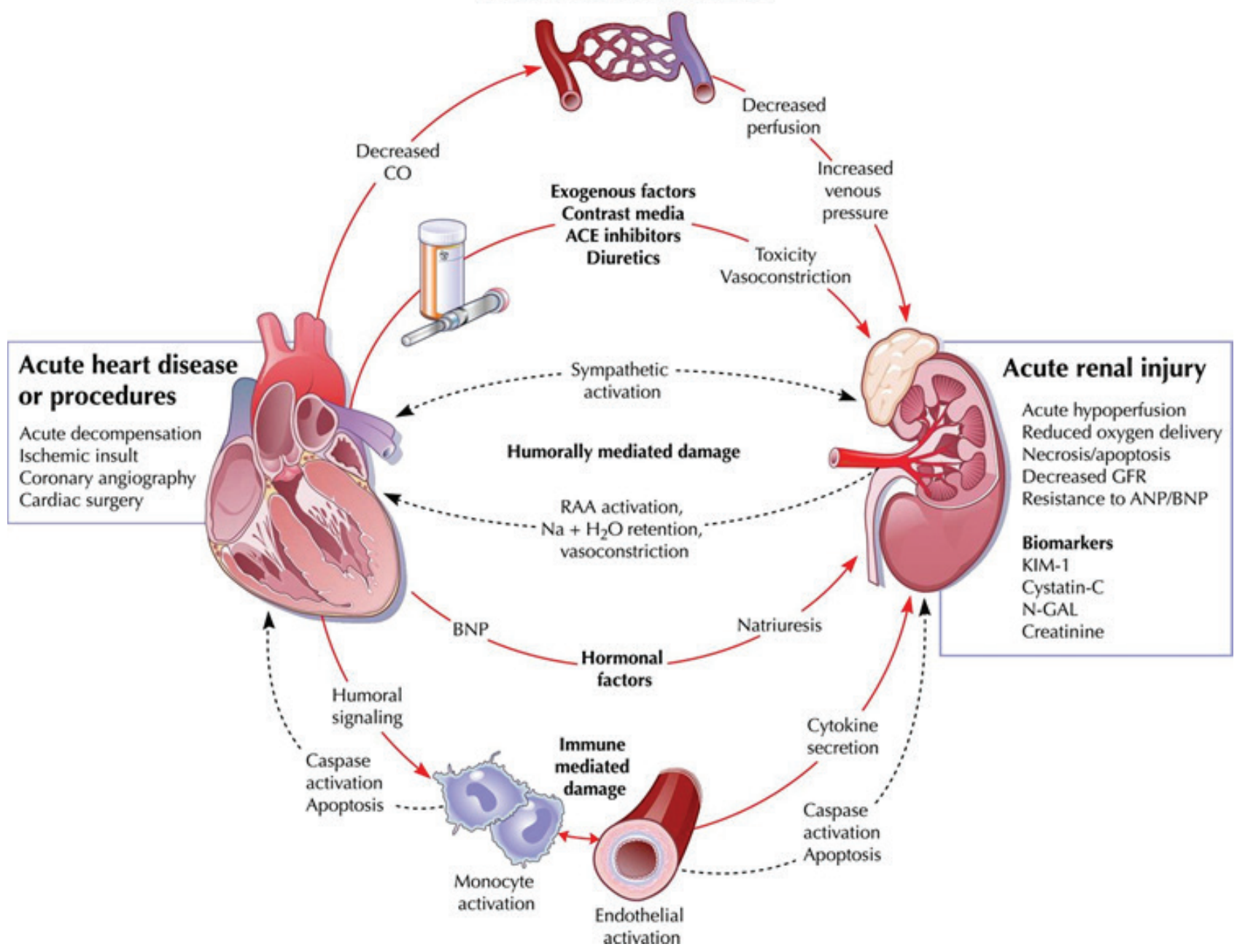

Figure 1. Pathophysiology of Type 1 CRS. ${ }^{[5]}$ 
patients with acute decompensated heart failure. ${ }^{16}$ 17] Many pathophysiological processes lead to AKI which includes epithelial and endothelial cell death and a major role for apoptotic mechanism due to ureteral obstruction, radiation, toxic injury and kidney ischemia. ${ }^{[18]}$ Loss of structure and function of epithelial cells leading to cell death by necrosis and apoptosis is due to renal tubular epithelium being more prone to ischemic injury. During AKI, renal tubular cells are major place of cellular damage with strong connection between renal cell apoptosis and intra-renal inflammatory activity. $\left.{ }^{[19} 20\right]$

\section{Diagnosis}

In type 1 CRS many biomarkers have been theorized for early diagnosis of kidney injury.

Cystatin C shows a better option to renal function as it predicts long term mortality and rehospitalization for acute decompensated heart failure than serum BNP or serum creatinine. Other markers include neutrophil gelatinase-associated lipocalin
(NGAL), liver type fatty acid-binding protein [L-FABP] and interleukin-18 [IL-18] and kidney injury molecule 1 [KIM-1]..$^{[4041]}$ Kidney ultrasound highlights normal or larger dimensions with preserved cortical medullary ratio, while colour doppler exam highlights regular intraparenchymal blood flow which is often related with raised resistance index. Echocardiography highlights abnormal myocardial kinetics which include ischemic episode and left ventricular hypertrophy along with valvular disorders, pericardial effusions, aortic aneurysms and collapse of inferior vena cava. ${ }^{[42]}$

\section{Management}

Inotropic agents are the main therapy for depressed myocardium and correction of underlying cause including ischemia which will reduce kidney injury and improve outcome. Angiotensin receptor blockers, ACE inhibitors, beta blockers and diuretics should be prescribed to patients with acute decompensated heart failure. ${ }^{[43]}$

\section{Type 2: Chronic CRS}

\section{Pathophysiology}

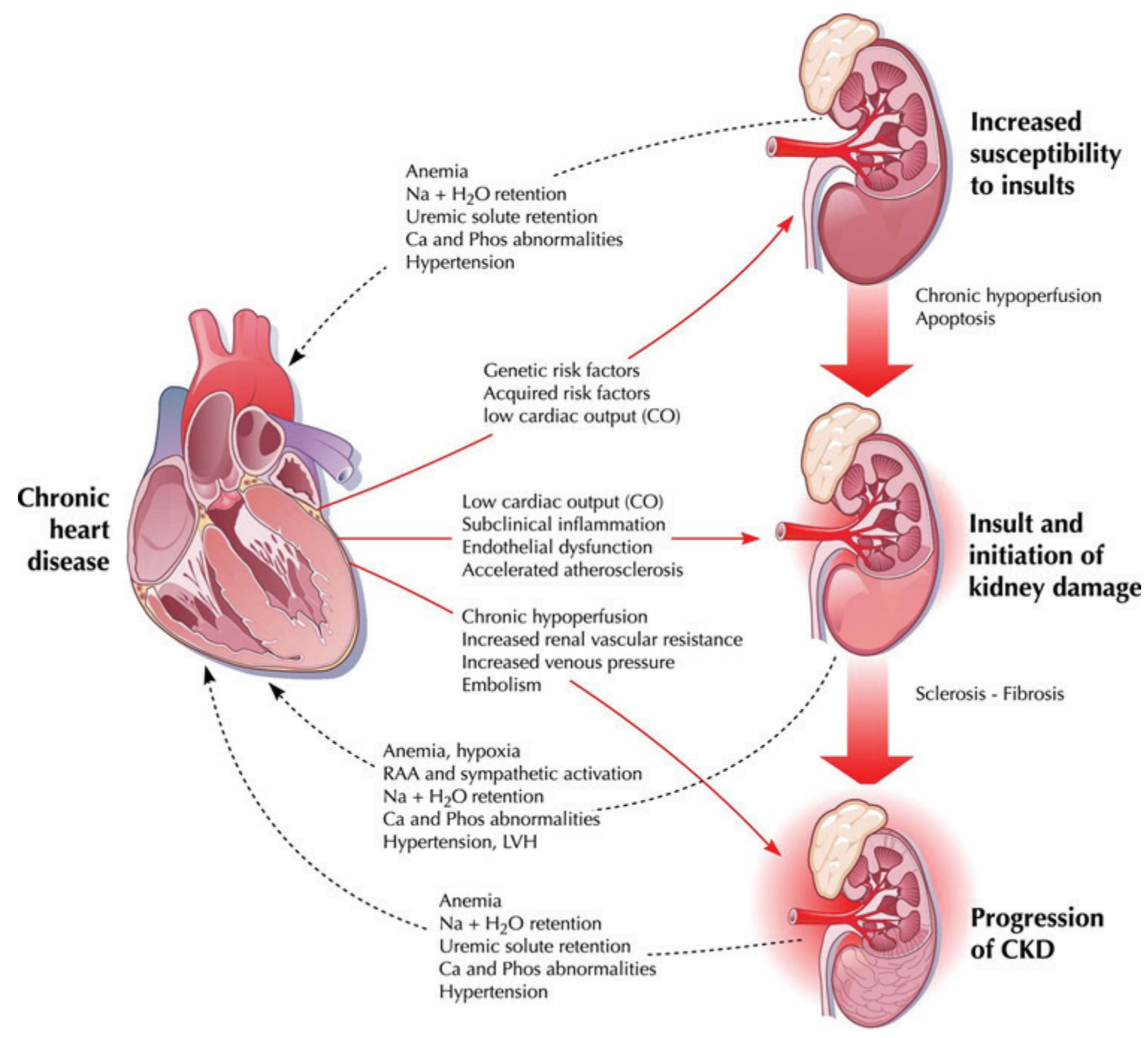

Figure 2. Pathophysiology of Type 2 CRS. ${ }^{[5]}$ 
Chronic heart failure and chronic kidney disease are simultaneously present in patients with type 2 CRS with chronic heart failure causing or progression to chronic kidney disease. Diseases such as congenital heart disease leading to cyanotic nephropathy or acute coronary syndrome which results in left ventricular dysfunction, thus causing the onset or progression of co-existing chronic kidney disease. Oxidative stress, atherosclerosis, inflammation, neuro-hormonal activation and renal hypoperfusion and venous congestion are main pathophysiological mechanisms and are present in recurrent episodes of kidney decompensation or heart failure. These are associated with heart failure and chronic kidney disease progression. ${ }^{21}{ }^{22]}$ Kidneys of patients in heart failure release huge quantity of renin leading to abnormal production of angiotensin II which in return causes increase in oncotic pressure of peritubular capillaries and efferent arteriolar constriction. Patients with preserved ejection fraction have worsening GFR due to high venous pressure. Chronic kidney disease progression is contributed by persistent sympathetic nervous system and RAAS activation. ${ }^{[23]}$ Angiotensin II production and aldosterone causes systemic pressure and volume overload due to reabsorption of sodium by distal nephrons. Increase in aldosterone also causes glomerular fibrosis by upregulating the transforming growth factor- $\beta$ (TGF- $\beta$ ) and increased secretion of fibronectin. In acute decompensated heart failure persistent inflammation triggered by continuous cardiac decompensation is also culprit for chronic kidney disease progression. ${ }^{[2425]}$

\section{Diagnosis}

Previously assessment of kidney injury in chronic heart failure have been restricted to creatinine and urinary protein excretion assays. Renal biomarkers such as cystatin C, NGAL, KIM-1 and N-acetyl- $\beta$-D-glycosaminidase - NAG are prognostic in cardiovascular but not in renal outcome. Patients with reduced or preserved left ventricular ejection fraction along with GFR and albuminuria are prognostic for renal outcomes in chronic kidney disease patients but not in heart failure patients. ${ }^{[44}$ 45] Echocardiography highlights increase atrial volume overload, decreased or increased ejection fraction, high pulmonary arterial pressure, valvular disease, pericardial effusion and right chamber dilation. Ultrasound of kidney highlights increased parenchymal echogenicity, decreased cortical thickness and decreased corticomedullary ratio. ${ }^{[42]}$

\section{Management}

Counteracting renal dysfunction once it has established and preventing new episode of renal dysfunction in chronic heart disease is main issue in type 2 CRS. Chronic heart failure drugs can worsen renal function. Early introduction of RAAS blockade, drug induced hypotension and diuresis associated hypovolemia can initiate or aggregate the type 2 CRS. Combination of thiazide and loop diuretics therapy can be applicable however use of high doses of loop diuretics is discouraged due to side effects such as hypokalaemia, hypotension, neurohormonal activation and renal impairment. When standard management such as diuretics fails, use of isolated ultrafiltration to correct fluid overload is justified. $\left.{ }^{466} 4748\right]$

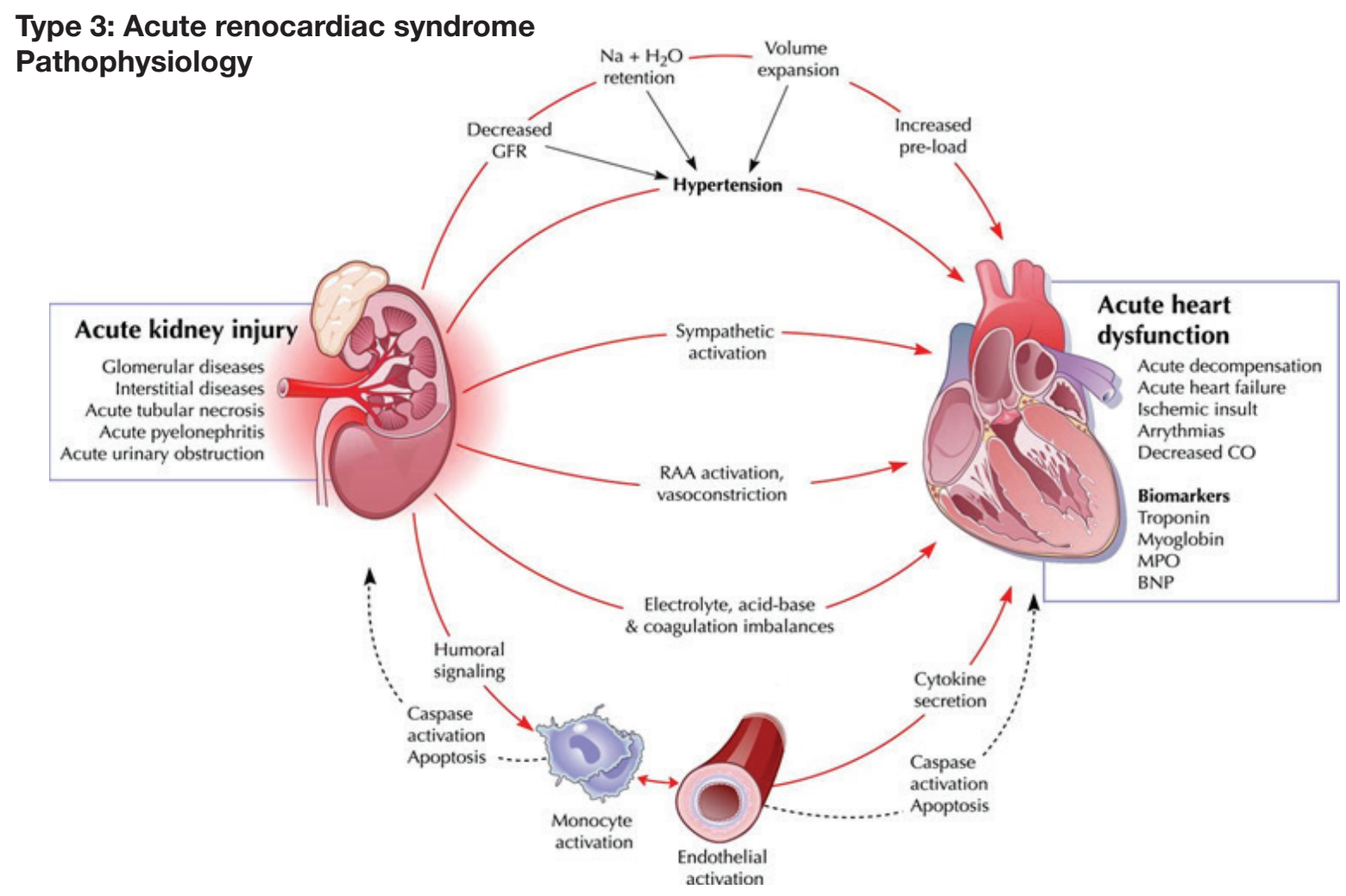

Figure 3. Pathophysiology of Type 3 acute renocardiac syndrome. ${ }^{[5]}$ 
Acute kidney injury can directly or indirectly lead to acute heart dysfunction. Direct include immune modulation (release of pro and anti-inflammatory cytokines and chemokines), coagulation cascade activation and hyperactivity of RAAS and sympathetic nervous system. Indirect include oliguria due to declining renal function leading to water and sodium retention resulting in fluid volume overload, hypertension, pulmonary edema and eventually myocardial injury. Electrolyte abnormalities (especially hyperkalaemia leading to arrythmias and hypocalcaemia), metabolic acidosis and uraemia can also affect heart acutely. Acute kidney injury also affects acute left ventricular dysfunction and accelerated fibrosis. [26 27 28]

\section{Diagnosis}

Ultrasound of kidney shows kidney size and echogenicity providing primary features to distinguish between acute and chronic nephropathies however normal or enlarged kidney as seen in early stages of diabetic nephropathies, cast nephropathy and HIV related glomerulonephritis should not be excluded in determining chronic kidney failure. ${ }^{[42]}$ AKI biomarkers include neutrophil gelatinase-associated lipocalin (NGAL), liver type fatty acid-binding protein [L-FABP] and interleukin-18 [IL-18] and kidney injury molecule 1 [KIM-1]. ${ }^{[40}{ }^{41]}$ Cardiac biomarkers include NT pro BNP and troponins. ${ }^{[49]}$

\section{Management}

Complete management of type 3 requires identification of various stages of disease according to RIFLE/AKIN criteria including patient at high risk of developing AKI, stage 1 (risk), stage 2 (injury) and stage 3 (failure). In patients at high risk of developing AKI, nephrotoxic medication should be minimized or avoided including standard or combination therapies, antibiotics such as aminoglycosides, ACE inhibitors, non-steroidal anti-inflammatory drugs and diuretics. These medications cause volume depletion and renal tubular injury. Prevention of hypoperfusion plays a major role in avoidance of AKI and fluid overload monitoring in patients with higher filling pressure and signs of right heart dysfunction due to increased preload to prevent further damage to the heart. In stage 1 (risk) patient at risk develop severe AKI and acute renal failure. Treatment is similar to patients at high risk of developing AKI. However routine blood tests, urine analysis, biomarkers and ultrasound studies can help in determining the cause, therefore resulting in appropriate management plan. Stage 2 (injury) is characterized by high risk of morbidity and mortality due to kidney injury; Conservative therapy, functional hemodynamic monitoring, electrolyte and acid base homeostasis monitoring can aid in resuscitation of patients. Stage 3 (failure) is life threatening and extracorporeal kidney support should be considered if drug therapy fails..$^{[50]}$

Chronic kidney disease (CKD) can accelerate ischemic heart disease and lead to volume and pressure overload resulting in left ventricular hypertrophy and congestive heart failure. Left ventricular hypertrophy can initiate as early as CKD 2 but is more prevalent in CKD 5 or pre haemodialysis patients. [29 30] Dyslipidaemia, hyperhomocysteinemia, insulin resistant and chronic inflammation contribute to progressive cardiovascular disease in chronic kidney disease as GFR declines and slow build-up of range of toxins such as phenols, indoles etc occurs. Secondary hyperparathyroidism and hyperphosphatemia can initiate cardiac vessels and valves ossification due to osteoblastic transformation of vascular smooth muscle. ${ }^{[31}{ }^{32]}$ Atrial fibrillation and ventricular tachyarrhythmias are more common in CKD 5 haemodialysis patients due to notable shifts in electrolytes and blood pressure volumes in intra and inter-dialytic periods resulting in myocardial cells mechanical and arrhythmogenic potential. Cardiac arrythmia and sudden death accounts for almost half of cardiovascular deaths in end stage kidney disease patients. ${ }^{[33}{ }^{34]}$ Chronic kidney disease patients have higher susceptibility of coronary arteriosclerotic heart disease. ${ }^{[35]}$ Uremic toxins contribute to cardiac fibrosis in chronic kidney disease patients similar to chronic ischemic heart disease and hypertensive patients in which endocardial and epicardial fibrosis prevails. $\left.{ }^{[36} 37\right]$

\section{Diagnosis}

NT-Pro BNP serum levels are used to assess cardiac function while GFR is used to asses kidney function. ${ }^{[40]}$ Ultrasound of kidney shows chronic nephropathy highlighting thin and hyperechogenic cortex with decreased medullary ratio along with minute dilation of urinary tract. Echocardiography shows signs of volume overload including left and right ventricular dysfunction. ${ }^{[42]}$

\section{Management}

For better cardiovascular and renal outcome in elderly patients and also those in advanced chronic kidney disease the use of beta blockers with ACE inhibitors or angiotensin II receptor blocker have been observed. ${ }^{[51]}$

Type 5 secondary CRS pathophysiology depends on the underlying disease from systemic processes such as sepsis, toxins, drugs and connective tissue disorders including sarcoidosis and involve simultaneous injury to heart and kidneys. The development of type 5 secondary CRS is variable depending on the underlying disease in such that during sepsis there is an acute impact on kidney and heart leading to obvious clinical manifestation while during cirrhosis the impact is slow over a period of time until a critical point is crossed, and decompensation occurs. Sepsis can affect hypothalamus pituitary gland-adrenal gland axis, RAAS and autonomic nervous system independently which leads to impact on heart or kidney function.

Pro inflammatory mediators and complement factors have been theorized as crucial players during sepsis. ${ }^{[38}$ 39] 
Type 4: Chronic renocardiac syndrome Pathophysiology

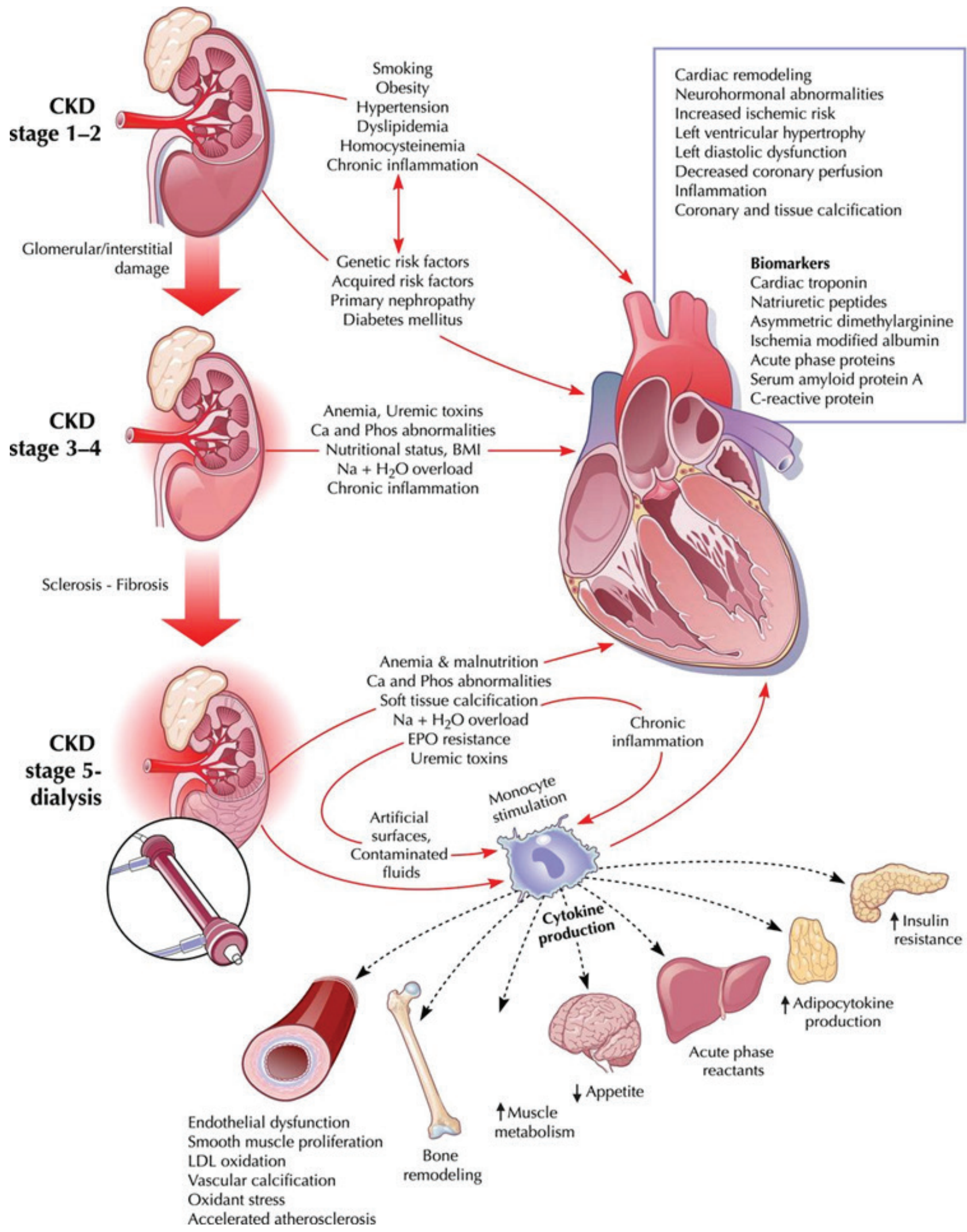

Figure 4. Pathophysiology of Type 4 chronic renocardiac syndrome. ${ }^{[5]}$ 
Type 5: secondary CRS

Pathophysiology

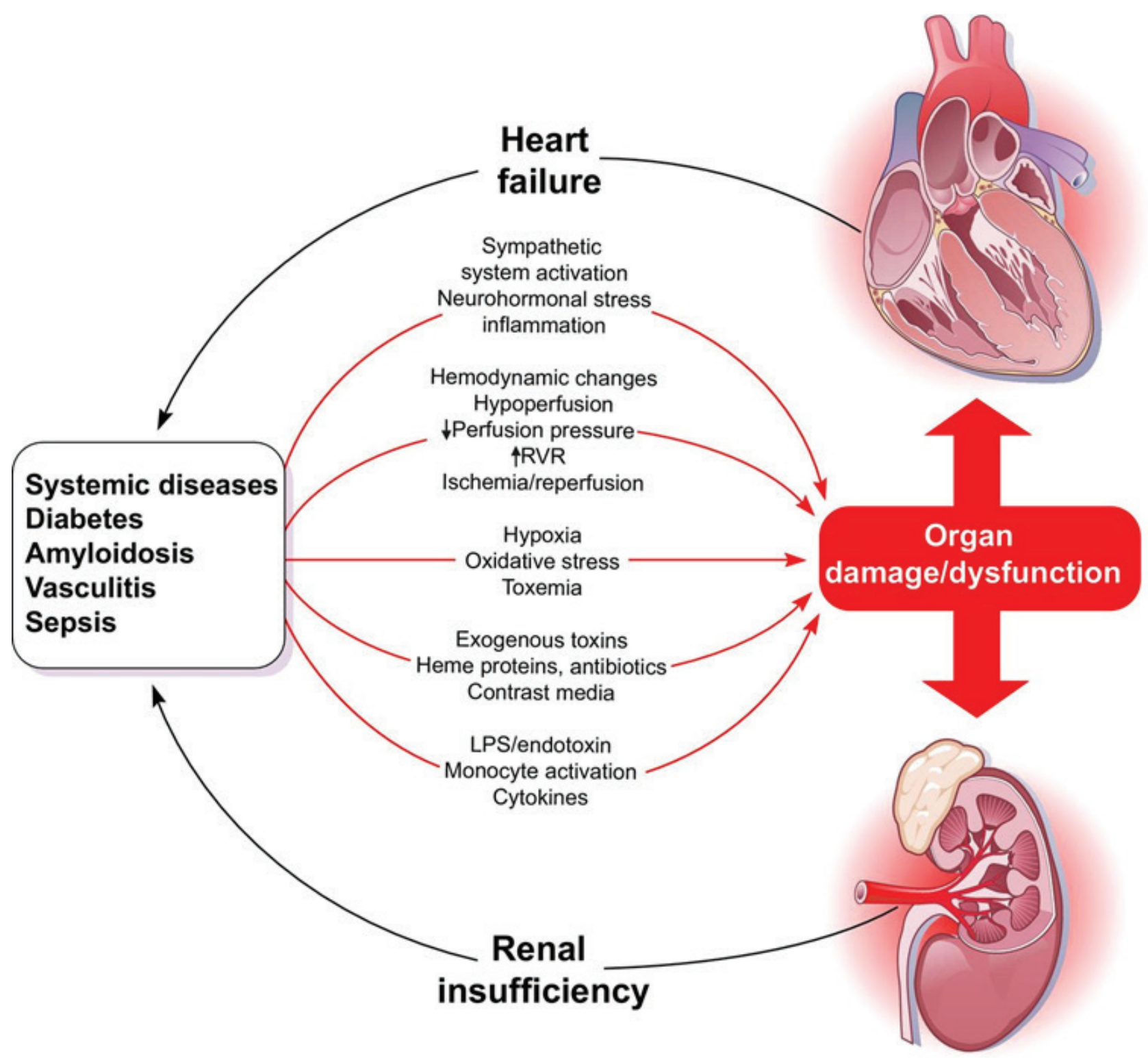

Figure 5. Pathophysiology of Type 5 secondary CRS. ${ }^{[5]}$

\section{Diagnosis}

During sepsis some biomarkers such as lipopolysaccharide-binding protein, procalcitonin, CRP and proinflammatory cytokines (IL-6, TGF- $\beta$ ) are elevated. ${ }^{[52]}$ NT-Pro BNP serum levels and troponins are used to assess cardiac function while GFR is used to asses kidney function. ${ }^{[40}{ }^{49]}$ Cardiomyopathy with dilation of left heart chambers and left ventricular regional contractility is seen in echocardiography. ${ }^{[42]}$

\section{Management}

To prevent type 5 CRS in hyperacute phase of sepsis, maintenance of hemodynamic stability and tissue perfusion with fluid control and correct anti- biotic treatment is the main key role. ${ }^{[53]}$ Removal of cytokines and immunomodulation can be achieved with high permeability membranes since immune disorders and inflammation plays a crucial role in pathogenesis of sepsis. ${ }^{[54]}$ Fluid therapy along with vasopressors, vasodilators and inotropes is needed to maintain filling pressures and to manage heart complications. Vasopressors have depressive effect on cardiac output so they should be carefully administered, Renal support include maintenance of adequate perfusion pressure, removal of nephrotoxic drug and dialysis if required. ${ }^{[53]}$ 


\section{Reference}

1. Janani, Rangaswami; Vivek, Bhalla; John, E.A. Blair; Tara, I. Chang; Salvatore, Costa; Krista, L. Lentine; Edgar, V. Lerma; Kenechukwu, Mezue; Mark, Molitch; Wilfried, Mullens; Claudio, Ronco; W.H. Wilson, Tang; Peter, A. McCullough. Cardiorenal Syndrome: Classification, Pathophysiology, Diagnosis, and Treatment Strategies: A Scientific Statement from the American Heart Association. Circulation. 2019; 139:e840-e878 https://doi. org/10.1161/CIR.0000000000000664

2. Ronco C, Bellasi A, Di Lullo L. Cardiorenal Syndrome: An Overview. Adv Chronic Kidney Dis. 2018; 25(5):382-390. doi: 10.1053/j.ackd.2018.08.004.

3. National Heart, Lung, and Blood Institute. NHLBI Working Group: cardio-renal connections in heart failure and cardiovascular disease, 2004. 2004. https://www.nhlbi.nih.gov/events/2004/cardio-renal-connections-heart-failure-and-cardiovascular-disease. Accessed March 05, 2020.

4. Ronco C, McCullough P, Anker SD, Anand I, Aspromonte N, Bagshaw SM, Bellomo R, Berl T, Bobek I, Cruz DN, Daliento L, Davenport A, Haapio $M$, Hillege $H$, House $A A$, Katz $N$, Maisel A, Mankad S, Zanco P, Mebazaa A, Palazzuoli A, Ronco F, Shaw A, Sheinfeld G, Soni S, Vescovo G, Zamperetti N, Ponikowski P. Cardio-renal syndromes: report from the Consensus Conference of the Acute Dialysis Quality Initiative.Eur Heart J. 2010; 31:703-711.

5. Ronco C, Haapio M, House AA, Anavekar N, Bellomo R. Cardiorenal syndrome.J Am Coll Cardiol. 2008; 52:1527-1539. doi: 10.1016/j. jacc.2008.07.051

6. Liang K.V, Williams A.W. Greene E.L. Redfield M.M. Acute decompensated heart failure and the cardiorenal syndrome. Crit Care Med. 2008; 36:S75-S88

7. Haldeman G.A, Croft J.B. Giles W.H, Rashidee A. Hospitalization of patients with heart failure: national hospital discharge survey 1985 to 1995. Am Heart J. 1999; 137:352-360.

8. Mebazaa A, Gheorghiade M, Pina I.L, et al. Practical recommendations for prehospital and early in-hospital management of patients presenting with acute heart failure syndromes. Crit Care Med. 2008; 36:S129-S139.

9. Bargshaw S.M. Cruz D.M. Aspromonte N. Epidemiology of cardio -renal syndromes: workgroup statements from the 7th ADQI Consensus Conference. Nephrol Dial Transplant. 2010;25:14061416.

10. Damman K. Navis G. Voors A.A. Worsening renal function and prognosis in heart failure: systematic review and meta-analysis. J Card Fail. 2007;13:599-608.

11. Hanada S., Takewa Y., Mizuno T., Tsukiyan T., Taenaka Y., Tatsumi E. Effect of the technique for assisting renal blood circulation on ischemic kidney in acute cardiorenal syndrome. J Artif Organs. 2012;15:140-145.

12. Stevenson L.W., Perloff J.K. The limited reliability of physical signs for estimating hemodynamics in chronic heart failure. JAMA. 1989;261:884-888.

13. Mullens W., Abrahams Z., Francis G.S. Importance of venous congestion for worsening of renal function in advanced decompensated heart failure. J Am Coll Cardiol. 2009;53:589-596.

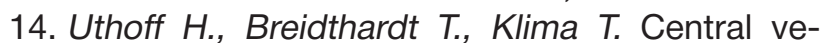
nous pressure and impaired renal function in patients with acute heart failure. Eur $\mathbf{J}$ Heart Fail. 2011;13:432-439.

15. Braam B., Cupples W.A., Joles J.A., Gaillard C. Systemic arterial and venous determinants of renal hemodynamics in congestive heart failure. Heart Fail Rev. 2012;17:161-175.

16. De Silva R., Loh H., Rigby A.S. Epidemiology, associated factors, and prognostic outcomes of renal artery stenosis in chronic heart failure assessed by magnetic resonance angiography. Am J Cardiol. 2007;100:273-279.

17. Nohria A., Tsang S.W., Fang J.C. Clinical assessment identifies hemodynamic profiles that predict outcomes in patients admitted with heart failure. J Am Coll Cardiol. 2003;41:1797-1804.

18. Havasi A, Borkan S.C. Apoptosis and acute kidney injury. Kidney Int. 2011;80:29-40.

19. Bonventre J.V. Dedifferentiation and proliferation of surviving epithelial cells in acute renal failure. J Am Soc Nephrol. 2003;14(Suppl. 1):S55-61.

20. Akcay A., Nguyen Q., Edelstein C.L. Mediators of inflammation in acute kidney injury. Mediators Inflamm. 2009:137072.

21. Cruz D.N., Schmidt-Ott K.M., Vescovo G. Pathophysiology of cardiorenal syndrome type 2 in stable chronic heart failure: workgroup statements from the eleventh consensus conference of the acute dialysis quality initiative (ADQI). Contrib Nephrol. 2013;182:117-136.

22. Setoguchi S., Stevenson L.W., Schneeweiss S. Repeated hospitalizations predict mortality in the community population with heart failure. Am Heart J. 2007;154(2):260-266.

23. Kanjanahattakij N, Sirinvaravong N, Aguilar F, Agrawal A, Krishnamoorthy $P$, Gupta S. High right ventricular stroke work index is associated with worse kidney function in patients with heart failure with preserved ejection fraction.Cardiorenal Med. 2018; 8:123-129. doi: 10.1159/000486629

24. Remuzzi G., Cattaneo D., Perico N. The aggravating mechanisms of aldosterone on kidney fibrosis. J Am Soc Nephrol. 2008;19(8):1459-1462.

25. Colombo P.C., Ganda A., Lin J. Inflammatory activation: cardiac, renal, and cardio-renal interactions in patients with the cardiorenal syndrome. Heart Fail Rev. 2012;17(2):177-190.

26. Yap S.C., Lee H.T. Acute kidney injury and extrarenal organ dysfunction: new concepts 
and experimental evidence. Anesthesiology. 2012;116(May (5)):1139-1148.

27. Prabhu S.D. Cytokine-induced modulation of cardiac function. Circ Res. 2004;95(December (12)):1140-1153.

28. Kingma J.G., Jr., Vincent C., Rouleau J.R., Kingma I. Influence of acute renal failure on coronary vasoregulation in dogs. J Am Soc Nephrol. 2006;17(May (5)):1316-1324.

29. Lezaic V., Tirmenstajn-Jankovic B., Bukvic D. Efficacy of hyperphosphatemia control in the progression of chronic renal failure and the prevalence of cardiovascular calcification. Clin Nephrol. 2009;71(1):21-29.

30. Di Lullo L., Floccari F., Santoboni A. Progression of cardiac valve calcification and decline of renal function in CKD patients. J Nephrol. 2013;26(July (4)):739-744.

31. Fort J. Chronic renal failure: a cardiovascular risk factor. Kidney Int. 2005;68(Suppl. 99):S25-S29.

32. Schiffrin E.L., Lipman M.L., Mann J.F. Chronic kidney disease: effects on the cardiovascular system. Circulation. 2007;116(1):85-97.

33. Chan C.T., Levin N.W., Chertow G.M. Determinants of cardiac autonomic dysfunction in ESRD. Clin J Am Soc Nephrol. 2010;5(10):1821-1827.

34. Winkelmayer W.C., Patrick A.R., Liu J. The increasing prevalence of atrial fibrillation among hemodialysis patients. J Am Soc Nephrol. 2011;22(2):349-357.

35. Cai Q., Mukku V.K., Ahmad M. Coronary artery disease in patients with chronic kidney disease: a clinical update. Curr Cardiol Rev. 2013;9(November (4)):331-339.

36. Kingma J.G., Jr., Vincent C., Rouleau J.R., Kingma I. Influence of acute renal failure on coronary vasoregulation in dogs. J Am Soc Nephrol. 2006;17(May (5)):1316-1324.

37. Lok D.J., Lok S.I., Bruggink-André de la Porte P.W. Galectin-3 is an independent marker for ventricular remodeling and mortality in patients with chronic heart failure. Clin Res Cardiol. 2013;102(February (2)):103-110.

38. Krag A., Bendtsen F., Burroughs A.K., Møller S. The cardiorenal link in advanced cirrhosis. Med Hypotheses. 2012;79(July (1)):53-55.

39. Lundy D.J., Trzeciak S. Microcirculatory dysfunction in sepsis. Crit Care Clin. 2009;25(4):721731.

40. Lassus JP, Nieminen MS, Peuhkurinen K, Pulkki $K$, Siirilä-Waris $K$, Sund $R$, Harjola VP; FINN-AKVA Study Group: Markers of renal function and acute kidney injury in acute heart failure: definitions and impact on outcomes of the cardiorenal syndrome. Eur Heart J. 2010;31:2791-2798.

41. Cruz DN, Gaiao S, Maisel A, Ronco C, Devarajan $P$ : Neutrophil gelatinase-associated lipocalin as a biomarker of cardiovascular disease: a systematic review. Clin Chem Lab Med. 2012;50:1533-1545.

42. Di Lullo L, Floccari F, Granata A, D’Amelio A, Rivera R, Fiorini F, Malaguti M, Timio M: Ultrasonography: Ariadne's thread in the diagnosis of cardiorenal syndrome. Cardiorenal Med. 2012;2:11-17.

43. Hollenberg SM, Kevinsky CJ, Parrillo JE: Cardiogenic shock. Ann Intern Med. 1999;131:47-59.

44. Halbesma N, Jansen DF, Heymans MW, Stolk RP, de Jong PE, Gansevoort RT: Development and validation of a general population renal risk score. Clin J Am Soc Nephrol. 2011;6:1731-1738.

45. Cruz DN, Fard A, Clementi A, Ronco C, Maisel $A$ : Role of biomarkers in the diagnosis and management of cardio-renal syndromes. Semin Nephrol. 2012;32:79-92.

46. Shah SU, Anjum S, Littler WA: Use of diuretics in cardiovascular diseases: (1) heart failure. Postgrad Med J. 2004;80:201-205.

47. Butler J, Forman DE, Abraham WT, et al: Relationship between heart failure treatment and development of worsening renal function among hospitalized patients. Am Heart J. 2004;147:331338.

48. Costanzo MR: Ultrafiltration in the management of heart failure. Curr Opin Crit Care. 2008;14:524530.

49. Di Lullo L, Barbera V, Santoboni A, Bellasi A, Cozzolino $M$, De Pascalis A, Rivera $R$, Balducci $A$, Russo D, Ronco C: Troponins and chronic kidney disease. G Ital Nefrol. 2015;32.

50. Chuasuwan A, Kellum JA: Cardio-renal syndrome type 3: epidemiology, pathophysiology, and treatment. Semin Nephrol. 2012;32:31-39.

51. Cice G, Ferrara L, D’Andrea A, D'lsa S, Di Benedetto A, Cittadini A, Russo PE, Golino P, Calabro $R$ : Carvedilol increases two-year survival in dialysis patients with dilated cardiomyopathy: a prospective, placebo-controlled trial. J Am Coll Cardiol. 2003;41:1438-1444.

52. Reinhart K, et al: New approaches to sepsis: molecular diagnostics and biomarkers. Clin Microbiol Rev. 2012;25:609-634.

53. Ronco C, Di Lullo L: Cardiorenal syndrome. Heart Fail Clin. 2014;10:251-280.

54. Nakamura $M$, et al: Treatment of severe sepsis and septic shock by CHDF using a PMMA membrane hemofilter as a cytokine modulator. Contrib Nephrol. 2010;166:73-82.

\section{PEЗЮME}

\section{КАРДИОРЕНАЛЬНЫЙ СИНДРОМ: ОБЗОР СОВРЕМЕННОГО ПОНИМАНИЯ ПРОБЛЕМЫ}

Омур Аслам

Великобритания, Королевская больница графства Суррей 
Введение. Почки и сердце полагаются друг на друга в своем нормальном функционировании. Для работы почек им требуется адекватный кровоток, доставка кислорода и питательных веществ. Если развивается сердечная недостаточность, сердечный выброс снижается, что приводит к снижению почечного кровотока, что может привести к обратимому, а иногда и необратимому повреждению почек. Для функционирования сердца требуется регулирование внеклеточного объема, Если внеклеточный объем слишком низкий, объем крови недостаточен для поддержания сердечного выброса, а если внеклеточный объем слишком велик, жидкость вытекает из капилляров, что приводит к отекам.

Цель. Изучить взаимосвязи динамического равновесия системы «почки-сердце» в норме и при патологии.

Материал и методы. Обзор современных и зарубежных литературных источников; методики - описание, анализ, реферирование.

Результаты и их обсуждение. Проанализированы 5 форм кардиоренального синдрома, особенности классификации, патогенеза, клинических проявлений, динамика нарушения равновесия в системе «почки-сердце», вопросы коррекции этих нарушений. Они включают в себя лечение болезней почек и сердечно-сосудистой патологии, предупреждение развития сердечно-сосудистой недостаточности в соответствии с современными рекомендациями; диету; отказ от курения, алкоголя, нефротоксичных веществ; контроль массы тела, артериального давления, гликемии; применение ингибиторов ангиотензинпревращающего фермента, антагонистов рецепторов ангиотензина или блокаторов ангиотензиновых рецепторов, статинов; снижение внутрибрюшного давления и другие.

Выводы. Важны подходы к профилактике и лечению кардиоренального синдрома у больных с поражением почек и сердца. Необходима разработка и внедрение новых подходов к нефропротекции у больных с кардиоренальным синдромом, что возможно при совместной работе мультидисциплинарной команды.

Ключевые слова: почки, сердце, кардио-ренальный синдром.

\section{PЕЗЮME}

\section{КАРДІОРЕНАЛЬНИЙ СИНДРОМ: ОГЛЯД СУЧАСНОГО РОЗУМІННЯ ПРОБЛЕМИ}

\section{Омур Аслам \\ Велика Британія, Королівська лікарня графства Суррей}

Вступ. Нирки і серце доповнюють один на одного у своєму нормальному функціонуванні. Для роботи нирок їм потрібен адекватний кровоток, доставка кисню та поживних речовин. Якщо розвивається серцева недостатність, серцевий викид зменшується, що призводить до зменшення початкового кровотоку, що може привести до зворотнього, а іноді і незворотнього по- шкодження нирок. Для функціонування серця потрібно регулювання внутрішньоклітинного об'єму, якщо позаклітинний об'єм занадто низький, його не вистачає для підтримки серцевого викиду, а якщо позаклітинний об'єм занадто великий, рідина виходить з капілярів, що приводить до набряків.

Мета. Вивчити взаємозв'язок динамічної рівноваги системи «нирки-серце» в нормі і при патології.

Матеріал і методи. Огляд сучасних та іноземних літературних джерел; методики - опис, аналіз, реферування.

Результати та їх обговорення. Проаналізовані 5 форм кардіоренального синдрому, особливості класифікації, патогенез, клінічні прояви, динаміка порушень рівноваги в системі «нирки-серце», питання корекції цих порушень. Вони включають в себе лікування хвороби нирок та серцево-судинні розлади, попередження розвитку серцево-судинної недостатності відповідно до сучасних рекомендацій; дієту; відмову від паління, вживання алкоголю, нефротоксичних речовин; контроль маси тіла, артеріального тиску, глікемії; застосування інгібіторів ангіотензинперетворюючого ферменту, антагоністів рецепторів ангіотензину або блокаторів ангіотензинових рецепторів, статинів; зниження внутрішньочеревного тиску та інші.

Висновки. Важливі підходи до профілактики та лікування кардіоренального синдрому у хворих із ураженням нирок і серця. Необхідність розробки та введення нових підходів до нефропротекції у хворих з кардіоренальним синдромом, що можливо за умови співпраці у мультидисциплінарній команді.

Ключові слова: нирки, серце, кардіоренальний синдром.

\section{АВТОРСЬКА ДОВІДКА}

Omur Aslam

United Kingdom, Royal Surrey County hospital, Egerton, Rd, Guildford, GU2 7XX, biomedical scientist

tel.: +447746077400

E-mail: scientist8240@gmail.com

\section{Омур Аслам}

Великобритания, Королевская больница графства Суррей, Эгертон, Роуд, Гилфорд, GU2 7XX, ученый-биомедик моб .: +447746077400

E-mail: scientist8240@gmail.com

\section{Омур Аслам}

Велика Британія, Королівська лікарня графства Суррей, Егертон, Роуд, Гілфорд, GU2 7XX, вчений-біомедик

моб.$:+447746077400$

E-mail: scientist8240@gmail.com

Стаття надійшла до редакції 23.11.20 p. 